\title{
Pretreatment with saturated and unsaturated fatty acids regulates fatty acid oxidation in Madin-Darby bovine kidney cells
}

\author{
K. E. Boesche ${ }^{1}$ (1) and S. S. Donkin ${ }^{2 *}$ (1) \\ ${ }^{1}$ Purina Mills Inc., Gray Summit, MO 63039 \\ ${ }^{2}$ Department of Animal Sciences, Purdue University, West Lafayette, IN 47906
}

\begin{abstract}
Metabolic fates of fatty acids in tissue may be influenced by extracellular concentration and profile of fatty acids. Previous work has demonstrated the ability of $\mathrm{C} 18: 3 \mathrm{n}-3$ cis to ameliorate the effects of $\mathrm{C} 16: 0$ - or C18:0-induced depression of pyruvate carboxylase $(P C)$ mRNA expression. Pyruvate carboxylase catalyzes oxaloacetate synthesis and connects gluconeogenesis from lactate and fatty acid metabolism. Our objective was to determine the effects of co-presence of saturated and unsaturated fatty acids on cellular partitioning of $\left[1-{ }^{14} \mathrm{C}\right] \mathrm{C} 16: 0$ metabolism to $\mathrm{CO}_{2}$ or acid-soluble products (ASP) in Madin-Darby bovine kidney cells and the role of PC in this relationship. We hypothesized that the ratio of saturated to unsaturated fatty acid pretreatments regulates $\left[1-{ }^{14} \mathrm{C}\right] \mathrm{C} 16: 0$ partitioning to $\mathrm{CO}_{2}$ or ASP. Cells were exposed for $21 \mathrm{~h}$ to either individual fatty acids, C16:0, C18:0, C18:1n-9 cis, or C18:3n-3 cis, or to fatty acid combinations in 10:90, 25:75, 50:50, 75:25, or 90:10 ratios for 3 combinations: C16:0/C18: 3n-3 cis, C18:0/C18:3n-3 cis, or C18:1n-9 cis/C18:3n-3 cis. Total fatty acid concentration was $1.0 \mathrm{~m} M$ during the 21-h pretreatment phase. Following the 21-h incubation phase with fatty acid combinations, cells were incubated in the presence of $1.0 \mathrm{mM}\left[1-{ }^{14} \mathrm{C}\right] \mathrm{C} 16: 0$ for 3 $\mathrm{h}$ to determine the rate of metabolism to $\mathrm{CO}_{2}$ and ASP collection (per $\mu \mathrm{g} \mathrm{DNA}{ }^{-1} \cdot \mathrm{h}^{-1}$ ). Pretreatment with either C16:0 or C18:0 alone significantly depressed subsequent oxidation of $\left[1-{ }^{14} \mathrm{C}\right] \mathrm{C} 16: 0$ to ASP by 62.7 and $41.2 \%$, respectively, compared with C18:3n-3 cis pretreatment. Similar patterns were observed for $\left[1-{ }^{14} \mathrm{C}\right] \mathrm{C} 16$ :0 oxidation to $\mathrm{CO}_{2}$. Expression of $P C$ mRNA was significantly decreased with exposure to either C16:0 or C18:0 compared with expression after exposure to either C18:3n-3 cis or control 1\% BSA in Dulbecco's modified Eagle's medium. Expression of cytosolic phosphoenolpyruvate carboxykinase (PCK1) mRNA followed a similar pat-
\end{abstract}

Received April 28, 2020.

Accepted May 29, 2020.

*Corresponding author: sdonkin@purdue.edu tern. Fatty acid treatments containing C18:1n-9 cis did not alter $P C$ or $P C K 1$ expression from control or C18:3n-3 cis results. Pearson coefficient correlations were determined for $P C$ mRNA expression and rate of $\left[1-{ }^{14} \mathrm{C}\right] \mathrm{C} 16: 0$ metabolism to $\mathrm{CO}_{2}$ or ASP, including ketones, and for PCK1 mRNA expression and rate of $\left[1-{ }^{14} \mathrm{C}\right] \mathrm{C} 16: 0$ metabolism to $\mathrm{CO}_{2}$ or ASP. Production of $\mathrm{CO}_{2}$ from $\left[1{ }^{14} \mathrm{C}\right] \mathrm{C} 16: 0$ was positively correlated $(\mathrm{r}$ $=0.63$ ) with $P C$ expression, whereas ASP production from $\left[1-{ }^{14} \mathrm{C}\right] \mathrm{C} 16: 0$ only tended to positively correlate $(\mathrm{r}=0.51)$ with $P C$ mRNA expression. Production of $\mathrm{CO}_{2}$ or ASP from $\left[1-{ }^{14} \mathrm{C}\right] \mathrm{C} 16$ :0 were both positively correlated $(\mathrm{r}=0.80$ and $\mathrm{r}=0.69$, respectively) with $P C K 1$ expression. Results show a regulation of ketone production by Madin-Darby bovine kidney cells in response to saturated and unsaturated fatty acid pretreatments. Key words: bovine, fatty acid oxidation, ketogenesis

\section{INTRODUCTION}

Pyruvate carboxylase (PC; EC 6.4.1.1) is a critical enzyme responsible for the anaplerotic regeneration of tricarboxylic acid cycle (TCA) intermediates. Conversely, phosphoenolpyruvate carboxykinase (PCK; EC 4.1.1.32) acts cataplerotically to drain carbon intermediates from TCA cycle toward gluconeogenesis. In cattle, the latter is represented by the combined activities of the cytosolic (PCK1) and mitochondrial (PCK2) forms of the enzyme, yet to date only PCK1 has been shown to be metabolically responsive (Zhang et al., 2015, 2016). Pyruvate carboxylase is responsible for the carboxylation of pyruvate to oxaloacetate (OAA), which subsequently condenses with acetyl-CoA in the first step of the TCA cycle; therefore, the capacity for fatty acid oxidation as well as gluconeogenesis depends on OAA status within the cell. As a result, the maintenance of the OAA pool through the action of PC flux could promote complete oxidation of acetyl-CoA in the TCA cycle, providing that PCK activity does not exceed PC flux (Jitrapakdee et al., 2006).

Nutritional control of PC is well established in rats (Bizeau et al., 2001), mice (Hagopian et al., 2004), and 
lactating dairy cows, specifically during a period of imposed feed restriction (Velez and Donkin, 2005) and transition to lactation (Greenfield et al., 2000). In periparturient dairy cows, plasma nonesterified fatty acid (NEFA) concentrations increase in response to the negative energy balance experienced around calving. After calving, plasma NEFA concentrations in excess of $1.5 \mathrm{mM}$ are observed, in contrast to concentrations near $0.2 \mathrm{~m} M$ during the prepartum period (Rukkwamsuk et al., 2000). Likewise, fatty acid concentration are transiently elevated in response to stress in calves (Sartorelli et al., 1992). Circulating NEFA are taken up by liver in proportion to their presence in blood (Emery et al., 1992) and are metabolized either through complete or partial oxidation or through triglyceride synthesis and subsequent deposition or loading onto very low density lipoprotein (VLDL) particles for export (reviewed by Drackley et al., 2001; Bobe et al., 2004; van Knegsel et al., 2005). Ruminants and nonruminants differ with respect to hepatic capacity for VLDL export, with the rate of export by nonruminants being 25 times the capacity of VLDL export for ruminants (Kleppe et al., 1988). Increases in triglyceride synthesis thus put dairy cows at increased risk for developing ketosis and fatty liver. Furthermore, overfeeding during the prepartum interval is linked to a decrease in the activity of hepatic enzymes involved in NEFA oxidation (Murondoti et al., 2004), an increase in activity of genes associated with liver triacyclglycerol synthesis (Loor et al., 2005), and a decrease in the rate of $\mathrm{C} 16: 0$ oxidation to $\mathrm{CO}_{2}$ (Litherland et al., 2011). Strategies to alleviate these pathways of fatty acid metabolism and promote alternative fatty acid oxidative pathways could potentially decrease susceptibility to these metabolic disorders in lactating cows. A similar metabolic flexibility may provide opportunities to alleviate metabolic stress in calves.

Increases in fatty acid concentration in plasma at calving and in response to feed restriction during lactation are primarily due to increased palmitic (C16:0), stearic (C18:0), and oleic (C18:1n-9 cis) acids with minor contributions from linoleic $(\mathrm{C} 18: 2 \mathrm{n}-6 \mathrm{cis})$ and linolenic (C18:3n-3) acids (Rukkwamsuk et al., 2000; Contreras et al., 2010). Fatty acids are known activators of transcription factors, including peroxisome proliferator-activated receptor- $\alpha$ (PPAR- $\alpha$; Jump, 2008) that exert control on gluconeogenesis through changes in gene expression. We have previously determined the direct effects of fatty acids on the bovine PC promoter 1 expression (White et al., 2012). We observed a repression of PC promoter 1 activity with stearic acid and palmitic acid, activation by PPAR- $\alpha$ agonists, and an increase in PC with a cocktail of fatty acids that resemble the plasma pattern observed at calving (White et al., 2012). The data suggest that overall PC expression is determined by the profile and overall concentration of NEFA. However, the role of $P C$ mRNA expression in relation to the potential for cellular complete or partial fatty acid oxidation remains unclear. Our objective was therefore to determine effects of co-presence of SFA and UFA pretreatments on cellular partitioning of $\left[1-{ }^{14} \mathrm{C}\right]$ C16:0 metabolism to $\mathrm{CO}_{2}$ or acid-soluble products (ASP) in Madin-Darby bovine kidney (MDBK) cells, a bovine model cell line for the study of cellular energy metabolism. We hypothesized that the ratio of SFA to UFA pretreatments regulates $\left[1-{ }^{14} \mathrm{C}\right] \mathrm{C} 16: 0$ partitioning to $\mathrm{CO}_{2}$ and ASP.

\section{MATERIALS AND METHODS}

\section{Cell Culture}

Madin-Darby bovine kidney epithelial cells (NBL-1 ATCC CCL-22) were obtained at passage 110 from the American Type Culture Collection (ATCC, Manassas, VA). Cells were propagated in sterile polystyrene $150-\mathrm{cm}^{2}$ canted-neck, $0.2-\mu \mathrm{m}$ vent cap flasks (Corning, Corning, NY) in Dulbecco's modified Eagle's medium (DMEM) containing $1 \mathrm{~g} / \mathrm{L}$ D-glucose, L-glutamine, and $110 \mathrm{mg} / \mathrm{L}$ sodium pyruvate (Life Technologies, Grand Island, NY) supplemented with $10 \%$ fetal bovine serum (FBS; Sigma-Aldrich Corp., St. Louis, MO), 100 units $/ \mathrm{mL}$ penicillin, $100 \mu \mathrm{g} / \mathrm{mL}$ streptomycin, and 250 $\mathrm{ng} / \mathrm{mL}$ amphotericin B (antibiotic-antimycotic solution; Sigma-Aldrich Corp.) at $37^{\circ} \mathrm{C}$ in $5 \% \mathrm{CO}_{2}$ and $95 \%$ air. Medium was refreshed every 2 to $3 \mathrm{~d}$. Cells were subcultured to near confluence following removal of medium with trypsin-EDTA (Sigma-Aldrich Corp.). Trypsin activity was inhibited by addition of $10 \mathrm{~mL}$ of fresh DMEM supplemented with 10\% FBS, 100 units/ $\mathrm{mL}$ penicillin, $100 \mu \mathrm{g} / \mathrm{mL}$ streptomycin, and $250 \mathrm{ng} /$ $\mathrm{mL}$ amphotericin B. For each experimental replicate, cells were plated onto 35-mm Falcon Primaria Easy Grip tissue culture dishes (Becton Dickinson, Lincoln Park, NJ) at a density of $5 \times 10^{5}$ cells per well and incubated in 10\% FBS DMEM with antibiotics, as indicated above, to achieve approximately $80 \%$ confluence before exposure to treatments. Experiments were conducted using 3 separate cell preparations and triplicate wells or plates within each replicate. Samples from triplicates were pooled within cell preparation and statistical analysis performed for the 3 independent cell preparations within each experiment.

\section{Assessment of Cellular Integrity}

To assess the effects of cell manipulation and fatty acid treatments on viability, MDBK cells were plated on 96-well cell culture plates and grown to $80 \%$ con- 
fluence. Medium was changed after $24 \mathrm{~h}$ and cells were incubated for $24 \mathrm{~h}$ at $37^{\circ} \mathrm{C}$ and exposed to the same treatment medium used for assessment of RNA expression. The TACS MTT Cell Proliferation Assay (Trevigen, Gaithersburg, MD) was used according to the manufacturer's directions to determine the effect of fatty acid treatment on cell viability.

\section{Fatty Acid Pretreatments}

Fatty acids C16:0, C18:0, C18:1n-9 cis, and C18:3n -3 cis (Sigma-Aldrich Corp.) were bound to BSA (Probumin; Millipore, Billerica, MA) in a 4:1 molar ratio as described previously (Berry et al., 1991). Cells at $80 \%$ confluence were cultured in DMEM and exposed for $21 \mathrm{~h}$ to either 1\% BSA (no addition control), $1.0 \mathrm{mM}$ individual fatty acid (bound to BSA), or combinations of fatty acids in 10:90, 25:75, 50:50, or 75:25 molar ratios from combinations of $\mathrm{C} 16: 0$ and $\mathrm{C} 18: 3 \mathrm{n}-3$ cis, and in 25:75, 50:50, 75:25, or 90:10 molar ratios from combinations of $\mathrm{C} 18: 0$ and $\mathrm{C} 18: 3 \mathrm{n}-3$ cis or $\mathrm{C} 18: 1 \mathrm{n}-9$ cis and C18:3n-3 cis. Total fatty acid concentration in each combination was $1.0 \mathrm{mM}$ and BSA concentration was $1 \%$. Pretreatments were applied in triplicate to 3 separate cell replicates.

\section{Measurement of Metabolic Flux}

Following exposure to pretreatments for $21 \mathrm{~h}$, cells were incubated in the presence of DMEM containing $1 \%$ BSA and $1.0 \mathrm{mM}\left[1-{ }^{14} \mathrm{C}\right] \mathrm{C} 16: 0$ for $3 \mathrm{~h}$ before $\mathrm{CO}_{2}$ and ASP collection, as previously described (Donkin and Armentano, 1994). Briefly, pretreatment medium was removed and each $35-\mathrm{mm}$ dish (base) was placed into a straight-sided, wide-mouth $60-\mathrm{mL}$ jar (Nalgene, Thermo Scientific, Waltham, MA) with lids modified to hold rubber plug-type stoppers (Kimble Chase, Vineland, NJ) and fitted with a hanging plastic center well (Kimble Chase). The MDBK cells were then incubated in DMEM containing 1\% BSA and $1.0 \mathrm{mM}$ BSA-bound C16:0 containing $1-{ }^{14} \mathrm{C}$ labeled $\mathrm{C} 16: 0$ (Perkin Elmer, Waltham, MA) at approximately 1,000,000 decays per minute (DPM) per flask. Cells were gassed with $95 \%$ $\mathrm{O}_{2}: 5 \% \mathrm{CO}_{2}$, immediately sealed, and incubated at $37^{\circ} \mathrm{C}$ for $3 \mathrm{~h}$. Incubations were terminated by the addition of $0.2 \mathrm{~mL}$ of $5 \mathrm{~N} \mathrm{HClO}_{4}$ injected through the stopper of the flask into the medium. A volume of $0.2 \mathrm{~mL}$ of phenethylamine was added to each hanging center well containing a filter paper wick to trap ${ }^{14} \mathrm{CO}_{2}$. Samples were incubated for $1 \mathrm{~h}$ at room temperature after which center wells were removed, placed in scintillation vials with scintillation cocktail (Ecolite; MP Biomedical LLC, Solon, $\mathrm{OH}$ ), and radioactivity was determined by liquid scintillation counting. The rate of fatty acid incorporation into ASP was determined from acidified medium. Medium was removed from plates and collected in $15-\mathrm{mL}$ conical tubes; then, plates were rinsed $2 \times$ with ice-cold saline and the saline rinse combined with the acidified medium. The collected medium and saline mixture was centrifuged for $10 \mathrm{~min}$ at $700 \times g$ and neutralized with $\mathrm{KOH}$; radioactivity was determined by liquid scintillation counting. The DNA content of each culture plate was determined as previously described (Labarca and Paigen, 1980). The rate of oxidation was determined and expressed as nanomoles of ${ }^{14} \mathrm{C}$ substrate metabolized to ${ }^{14} \mathrm{CO}_{2}$ per microgram of DNA per hour $\left({ }^{14} \mathrm{CO}_{2} \cdot \mu \mathrm{g} \mathrm{DNA}{ }^{-1} \cdot \mathrm{h}^{-1}\right)$. The rate of synthesis of ASP, including ketones, was expressed as nanomoles of ${ }^{14} \mathrm{C}$ substrate incorporated in ASP per microgram of DNA per hour $\left(\mathrm{ASP} \cdot \mu \mathrm{g} \mathrm{DNA}^{-1} \cdot \mathrm{h}^{-1}\right)$

\section{Cell Sample Collection, RNA Isolation, and Transcript Quantification}

A parallel incubation was completed utilizing the same passage of cells interrogated for the oxidation experiment. Cells were exposed to $\mathrm{C} 16: 0 / \mathrm{C} 18: 3 \mathrm{n}-3$ cis or $\mathrm{C} 18: 0 / \mathrm{C} 18: 3 \mathrm{n}-3$ cis fatty acid treatment combinations in the molar ratios described above. After exposure to treatments for $24 \mathrm{~h}$, medium was removed and cells were disrupted and lysed by adding $350 \mu \mathrm{L}$ of Buffer RLT (RNeasy Mini Kit, Qiagen Inc., Germantown, MD). Plates were shaken on an orbital shaker (Barnstead International, Dubuque, IA) for $10 \mathrm{~min}$ and cell lysates collected in a $1.5-\mathrm{mL}$ microcentrifuge tube. Lysates were stored at $-80^{\circ} \mathrm{C}$ until subsequent RNA isolation.

Cell lysates were homogenized by vortexing and processed using the RNeasy Mini kit according to manufacturer directions (Qiagen Inc.). Purified RNA was quantified for each sample by absorbance at 260 $\mathrm{nm}$ using a ND-1000 spectrophotometer (NanoDrop Technologies Inc., Wilmington, DE); sample integrity was determined by the ratio of absorbance at 260 to $280 \mathrm{~nm}$. Only samples with a ratio of $260: 280 \geq 1.8$ were used for further analysis. An aliquot of $1 \mu \mathrm{g}$ of purified RNA from each sample was reverse transcribed to cDNA using an Omniscript reverse transcriptase kit (Qiagen Inc., Thousand Oaks, CA), random decamers (Ambion, Foster City, CA) and oligo-dT (Qiagen Inc.). Abundance of cDNA for each sample was quantified using real-time PCR, Brilliant III Ultra-Fast SYBR Green QPCR Master Mix (Agilent Technologies Inc., Santa Clara, CA) and primers described below. The noreverse-transcriptase template control was formed by combining equal quantities of purified RNA from each sample. A cDNA pool was formed from equal quantities of cDNA from each sample and diluted with DNase-free 
water in a 1:4 dilution series to generate a standard curve. DNase-free water served as the no-template control. The abundance of $P C$ (EC 6.4.1.1), PCK1 (EC 4.1.1.32), and 18S (NCBI gene number 493779) mRNA was determined using quantitative real-time PCR. Primers were as follows: bovine PC, CCACGAGTTCTCCAACACCT (forward), TTCTCCTCCAGCTCCTCGTA (reverse); bovine PCK1, AGGGAAATAGCAGGCTCCAGGAAA (forward), CACACGCATGTGCACACACACATA (reverse); and bovine 18S, ACCCATTCGAACGTCTGCCCTATT (forward), TCCTTGGATTGTGGTAGCCGTTTCT (reverse). Reactions were as follows: 1 cycle at $95^{\circ} \mathrm{C}$ for $3 \mathrm{~min} ; 40$ cycles of $95^{\circ} \mathrm{C}$ for $10 \mathrm{~s}, 60^{\circ} \mathrm{C}$ for $20 \mathrm{~s}$; and 1 cycle of $95^{\circ} \mathrm{C}$ for $1 \mathrm{~min}, 55^{\circ} \mathrm{C}$ for $30 \mathrm{~s}$, and $95^{\circ} \mathrm{C}$ for $30 \mathrm{~s}$. Reaction efficiencies were between 90 and $110 \%$ based on standard curve analysis. All samples, standards, and controls were analyzed in triplicate and mean values normalized to $18 S \mathrm{mRNA}$ abundance within each sample. Data are expressed as arbitrary units of mRNA relative to $18 S$ abundance within sample. Abundance of $18 S$ mRNA measured via threshold cycle values was not affected by treatment $(P=0.77)$.

\section{Statistical Analysis}

Data were analyzed for normality using the Univariate procedure of SAS version 9.3 (SAS Institute Inc., Cary, NC). Analyses of variance was performed using PROC MIXED of SAS. The model accounted for the fixed effects of fatty acid pretreatment and the random effects of cell replicate. Means were considered different when $P<0.05$ and tended to differ if $0.05 \leq P$ $\leq 0.10$. Tukey-Kramer studentized adjustments were used for multiple comparisons to separate treatment means. Data are reported as least squares means with associated standard errors. Pearson correlation coefficients for $P C$ mRNA expression and $\left[1-{ }^{14} \mathrm{C}\right] \mathrm{C} 16: 0$ substrate conversion to either $\mathrm{CO}_{2}$ or ASP (nmol per $\mu \mathrm{g}$ $\mathrm{DNA}^{-1} \cdot \mathrm{h}^{-1}$ ) were obtained using PROC CORR (SAS Institute Inc.).

\section{RESULTS AND DISCUSSION}

Use of the MDBK cell line for the current study is supported by previous studies examining metabolism and activities of enzymes for gluconeogenesis and fatty acid oxidation (Bionaz et al., 2008a,b; Thering et al., 2009; White et al., 2012). Notable similarities have been illustrated between mRNA expression patterns in MDBK cells and liver from periparturient dairy cows (Bionaz et al., 2008b). The metabolic role of kidney to oxidize fatty acids, especially during times of increased circulating NEFA load (Salto et al., 1996; Huang et al.,
2006), further justifies the use of a kidney cell line for the current substrate oxidation experiments.

Analysis of cellular integrity after fatty acid treatments on MDBK cells by the TACS MTT Cell Proliferation Assay indicated significant $(P<0.05)$ reductions in cell viability of $18.3,24.4,19.5$, and $15.9 \%$ with the addition of $1.00 \mathrm{mM}$ C16:0, C18:0, C18:1n-9 cis, and C18:3n-3 cis, respectively, compared with viability levels of $10 \%$ FBS-treated controls in MDBK cells. Despite the effects of single fatty acids, any evaluated combination of 2 fatty acids did not differ $(P>0.10)$ for cell viability measurement from the control 1\% BSA DMEM (Figure 1). This indicates that a more optimal environment for cellular growth and proliferation occurs when any 2 of the fatty acids evaluated here were present in the treatment medium for MDBK cells. Previous work in the human hepatoblastoma HepG2 cell line demonstrated a high percentage of apoptosis, measured with DAPI (4',6-diamidino-2-phenylindole dihydrochloride), after 24-h treatment with $0.66 \mathrm{~m} M$ C16:0 (Ricchi et al., 2009). Percent apoptosis was significantly reduced when C18:1n-9 cis was added to treatment medium, even when total treatment concentrations equaled 1.0 or $2.0 \mathrm{~m} M$ (Ricchi et al., 2009). Similarly, when evaluated in a model of hepatic steatosis, human hepatocytes exhibited decreased cell viability after treatment with C16:0 alone (Chen et al., 2014). In the same study, treatments containing combinations of $\mathrm{C} 16: 0$ with $\mathrm{C} 18$ : 1n-9 cis were able to reduce the C16:0-induced inhibition of cell growth (Chen et al., 2014). Treatment combinations of $\mathrm{C} 16: 0$ with $\mathrm{C} 18: 1 \mathrm{n}-9$ cis were not evaluated in the current study. Fatty acid treatments combining C18:0 with C18:3n-3 cis have been studied in isolated rat primary hepatocytes (Zhang et al., 2011). Although exposure of hepatocytes to $0.25 \mathrm{~m} M$ C18:0 significantly reduced MTT-measured cell viability, cotreatment of $0.25 \mathrm{~m} M \mathrm{C} 18: 0$ with either 0.15 or 0.25 $\mathrm{m} M$ C18:3n-3 cis restored viability to levels similar to the control (Zhang et al., 2011). This knowledge base, combined with data from the current study, indicates that co-incubation with more than one fatty acid allows greater cellular viability, potentially from more closely mimicking in vivo circulating fatty acid concentrations. Consequently, these data support the value of any effects of fatty acid combinations on expression of PC or other transcripts. Although decreases were seen in cell viability in the current study under single fatty acid treatments compared with treatment combinations of fatty acids, these decreases did not occur from treatments containing multiple fatty acids. Furthermore, when observed in the presence of a single fatty acid, the effect on cell viability was considerably less than changes in gene expression and fatty acid metabolism. Therefore, gene expression data, discussed below with 


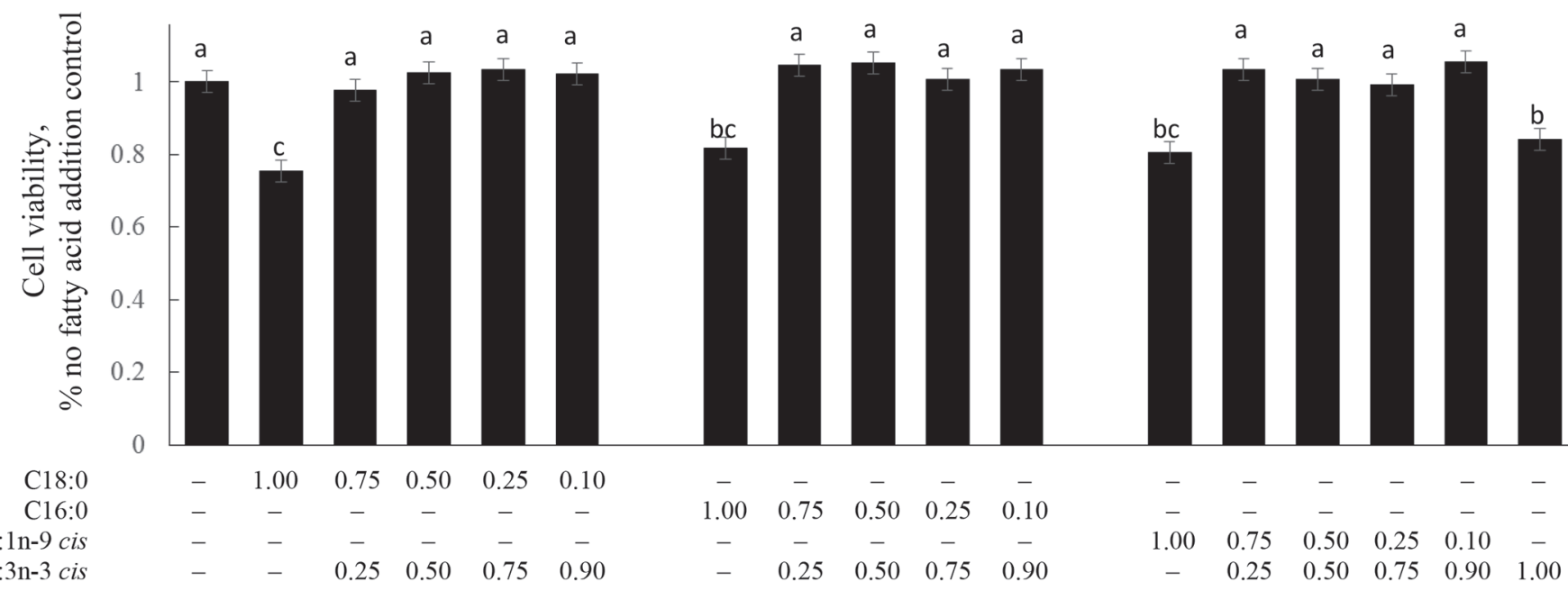

Fatty acid pretreatment $(\mathrm{m} M)$

Figure 1. Effect of 24-h fatty acid treatments on cellular viability in Madin-Darby bovine kidney (MDBK) cells. Cells were plated on 96well cell culture plates and grown to $80 \%$ confluence. Medium was changed after $24 \mathrm{~h}$ and cells were incubated for $24 \mathrm{~h}$ at $37^{\circ} \mathrm{C}$ and exposed to treatment medium. Fatty acid treatments were either single fatty acids (C16:0, C18:0, C18:1n-9 cis, or C18:3n-3 cis) or combinations of C16:0 with C18:3n-3 cis, or C18:0 with C18:3n-3 cis, or C18:1n-9 cis with C18:3n-3 cis, in the molar ratios indicated. All treatments totaled 1.0 m $M$ in Dulbecco's modified Eagle's medium (DMEM) with 1\% BSA. Control cells were incubated in DMEM with 1\% BSA and no additional fatty acid. The TACS MTT Cell Viability Assay (Trevigen, Gaithersburg, MD) was used according to the manufacturer's directions to determine the effect of fatty acid treatment on cell viability. Data are reported as least squares means with associated standard errors. Means without a common letter $(\mathrm{a}-\mathrm{c})$ differ $(P<0.05)$.

combinations of fatty acids, are not likely to be the result of differences in viability but are the result of fatty acid treatment.

Expression of $P C$ mRNA was significantly decreased $(P<0.05)$ after exposure to $1.0 \mathrm{~m} M \mathrm{C} 16: 0$ or $\mathrm{C} 18: 0$, compared with mRNA expression after exposure to C18:3n-3 cis or to control 1\% BSA DMEM (Table 1). To ameliorate this SFA-induced depression, treatment ratios greater than or equal to 0.25:0.75 C18:0/C18:3n -3 cis or 0.50:0.50 C16:0/C18:3n-3 cis were required to restore $P C$ mRNA expression to levels similar $(P$ $>0.10)$ to those after $1.0 \mathrm{~m} M \mathrm{C} 18: 3 \mathrm{n}-3$ cis treatment (Table 1). Expression of $P C$ mRNA did not differ $(P$ $>0.10$ ) after exposure, at any ratio, to C18:1n-9 cis. To better determine the balance of cataplerotic and anaplerotic responses occurring after exposure to fatty acid treatments, $P C K 1 \mathrm{mRNA}$ expression was also determined. Expression of $P C K 1 \mathrm{mRNA}$ was significantly decreased $(P<0.05)$ after exposure to $1.0 \mathrm{~m} M \mathrm{C} 16: 0$ or C18:0, compared with mRNA expression after exposure to C18:3n-3 cis or to control 1\% BSA DMEM (Table 1). Treatment ratios greater than or equal to 0.75:0.25 C16:0/C18:3n-3 cis or C18:0/C18:3n-3 cis were required to restore $P C K 1 \mathrm{mRNA}$ expression to levels similar $(P>0.10)$ to those after $1.0 \mathrm{~m} M$ C18: 3n-3 cis treatment (Table 1). Similar to results from $P C$ mRNA expression, treatments including any ratio of C18:1n-9 cis did not alter PCK1 mRNA expression.
Maintenance of activity or increased activity of either enzyme, using a proxy measure of mRNA expression (Greenfield et al., 2000), can be used to infer the pool size available for the cataplerotic or anaplerotic fate of OAA.

Fatty acid pretreatments in the current substrate oxidation study with either $1.0 \mathrm{mM}$ C16:0 or C18:0 alone significantly $(P<0.01)$ depressed subsequent oxidation of $\left[1-{ }^{14} \mathrm{C}\right] \mathrm{C} 16: 0$ to ASP by 62.7 and $41.2 \%$, respectively, compared with C18:3n-3 cis pretreatments in MDBK cells (Figure 2, 3). Similar patterns were seen for $\left[1-{ }^{14} \mathrm{C}\right]$ C16:0 oxidation to $\mathrm{CO}_{2}$. It is well established in rodent models that PUFA are capable of causing increases in both mitochondrial and peroxisomal oxidation, while leading to a decrease in esterification to triglycerides (Ikeda et al., 1998; Ide et al., 2000). Early studies in ruminants examining metabolism of $\mathrm{C} 16: 0$ to $\mathrm{CO}_{2}$ or ASP using bovine liver slices noted decreased oxidation to $\mathrm{CO}_{2}$ in liver samples from fasted, compared with control, animals, whereas fasting has no effect on C16:0 metabolism to ASP (Jesse et al., 1986). Dairy cows fed a high-fat diet during the dry period exhibited lower total liver lipid accumulation and lower liver triglyceride deposition during the postpartum period compared with cows receiving an isocaloric high-grain dry period diet or to the control (Grum et al., 1996). The same study illustrated increased prepartum plasma NEFA concentrations but decreased postpartum plasma NEFA 
Table 1. Pyruvate carboxylase $(P C)$ and cytosolic phosphoenolpyruvate carboxykinase $(P C K 1)$ mRNA expression after 24-h exposure to fatty acid treatments in Madin-Darby bovine kidney (MDBK) cells $^{1}$

\begin{tabular}{|c|c|c|c|c|c|c|c|c|c|}
\hline \multirow[b]{2}{*}{ Transcript } & \multicolumn{8}{|c|}{ Fatty acid treatment ${ }^{2}$ ratio: $\mathrm{C} 16: 0 / \mathrm{C} 18: 3 \mathrm{n}-3$ cis } & \multirow[b]{2}{*}{ SEM } \\
\hline & $0.00 / 0.00$ & $1.00 / 0.00$ & $0.90 / 0.10$ & $0.75 / 0.25$ & $0.50 / 0.50$ & $0.25 / 0.75$ & $0.10 / 0.90$ & $0.00 / 1.00$ & \\
\hline \multirow{2}{*}{$\begin{array}{l}P C \\
P C K 1\end{array}$} & $2.13^{\mathrm{ab}}$ & $0.25^{\mathrm{e}}$ & ND & $1.02^{\mathrm{d}}$ & $1.65^{\mathrm{bcd}}$ & $2.17^{\mathrm{abc}}$ & $2.31^{\mathrm{ab}}$ & $2.53^{\mathrm{a}}$ & 0.27 \\
\hline & \multicolumn{9}{|c|}{ Fatty acid treatment ratio: $\mathrm{C} 18: 0 / \mathrm{C} 18: 3 \mathrm{n}-3$ cis } \\
\hline \multirow{4}{*}{$\begin{array}{l}P C \\
P C K 1\end{array}$} & $2.42^{\mathrm{a}}$ & $0.13^{\mathrm{b}}$ & $0.46^{\mathrm{b}}$ & $2.01^{\mathrm{a}}$ & $2.13^{\mathrm{a}}$ & $2.26^{\mathrm{a}}$ & ND & $2.29^{\mathrm{a}}$ & 0.32 \\
\hline & $2.13^{\mathrm{bc}}$ & $0.06^{\mathrm{e}}$ & $0.59^{\mathrm{de}}$ & $1.28^{\mathrm{d}}$ & $1.60^{\mathrm{cd}}$ & $3.19^{\mathrm{a}}$ & ND & $2.53^{\mathrm{ab}}$ & 0.30 \\
\hline & \multicolumn{9}{|c|}{ Fatty acid treatment ratio: $\mathrm{C} 18: 1 \mathrm{n}-9$ cis/C18:3n-3 cis } \\
\hline & $0.00 / 0.00$ & $1.00 / 0.00$ & $0.90 / 0.10$ & $0.75 / 0.25$ & $0.50 / 0.50$ & $0.25 / 0.75$ & $0.10 / 0.90$ & $0.00 / 1.00$ & \\
\hline
\end{tabular}

${ }^{\mathrm{a}-\mathrm{e}}$ Within a fatty acid treatment ratio panel, means with different superscripts within transcript are significantly different $(P<0.05)$.

${ }^{1}$ Data are LSM for 3 separate cell preparations, with associated SEM. Data are presented as ratio of PC:18S mRNA expression or ratio of PCK1: $18 \mathrm{~S}$ mRNA expression (arbitrary units).

${ }^{2}$ Fatty acid treatments were either single fatty acids (C16:0, C18:0, C18:1n-9 cis, or C18:3n-3 cis) or combinations of C16:0 with C18:3n-3 cis (top), C18:0 with C18:3n-3 cis (middle), or C18:1n-9 cis with C18:3n-3 cis (bottom) in the molar ratios listed. All treatments totaled $1.0 \mathrm{~m} M$ in Dulbecco's modified Eagle's medium (DMEM) with 1\% BSA. Control treatment is DMEM with 1\% BSA and no additional fatty acid.

${ }^{3}$ Not determined.

concentrations in the high-fat group compared with the high-grain or control groups (Grum et al., 1996). This suggests that fatty acid $\beta$-oxidation is adjustable at transition as a potential mechanism for transition cows to cope with the excess NEFA load experienced during this period.

Treatment fatty acid levels in the current study totaled $1.0 \mathrm{mM}$ and were consistent with circulating

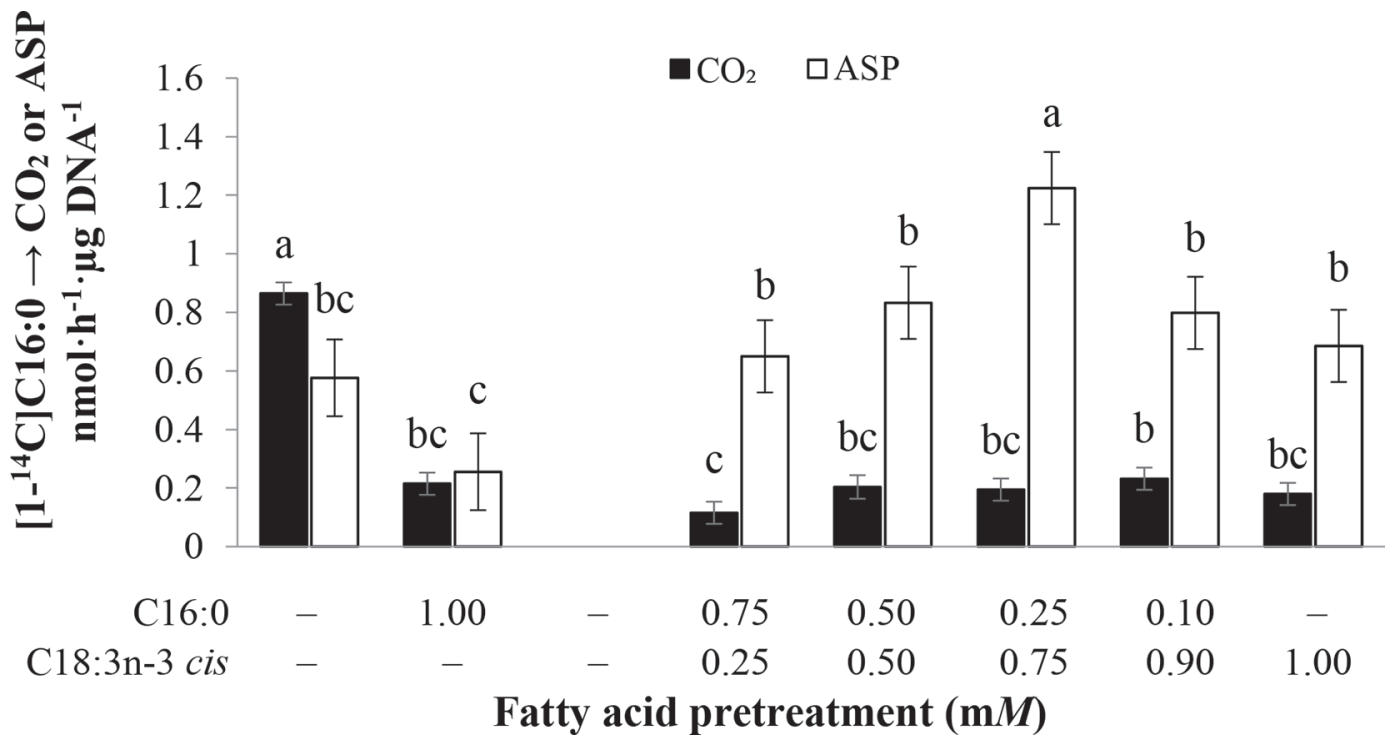

Figure 2. Oxidation of $\left[1-{ }^{14} \mathrm{C}\right] \mathrm{C} 16: 0$ to $\mathrm{CO}_{2}$ or acid-soluble products (ASP) after pretreatment with C16:0 and C18:3n-3 cis. Oxidation by Madin-Darby bovine kidney (MDBK) cells was measured over a 3-h period after 21-h pretreatments with BSA-bound fatty acids (FA). Fatty acid pretreatments were either single fatty acids (C16:0 or C18:3n-3 cis) or combinations of C16:0 with C18:3n-3 cis in the molar ratios listed. All treatments totaled $1.0 \mathrm{mM}$ in Dulbecco's modified Eagle's medium (DMEM) with 1\% BSA. Control is DMEM with 1\% BSA and no additional FA. Data are reported as least squares means for 3 separate cell preparations with associated standard errors. Within substrate fraction, $\mathrm{CO}_{2}$ or ASP, means without a common letter $(\mathrm{a}-\mathrm{c})$ differ $(P<0.05)$. 


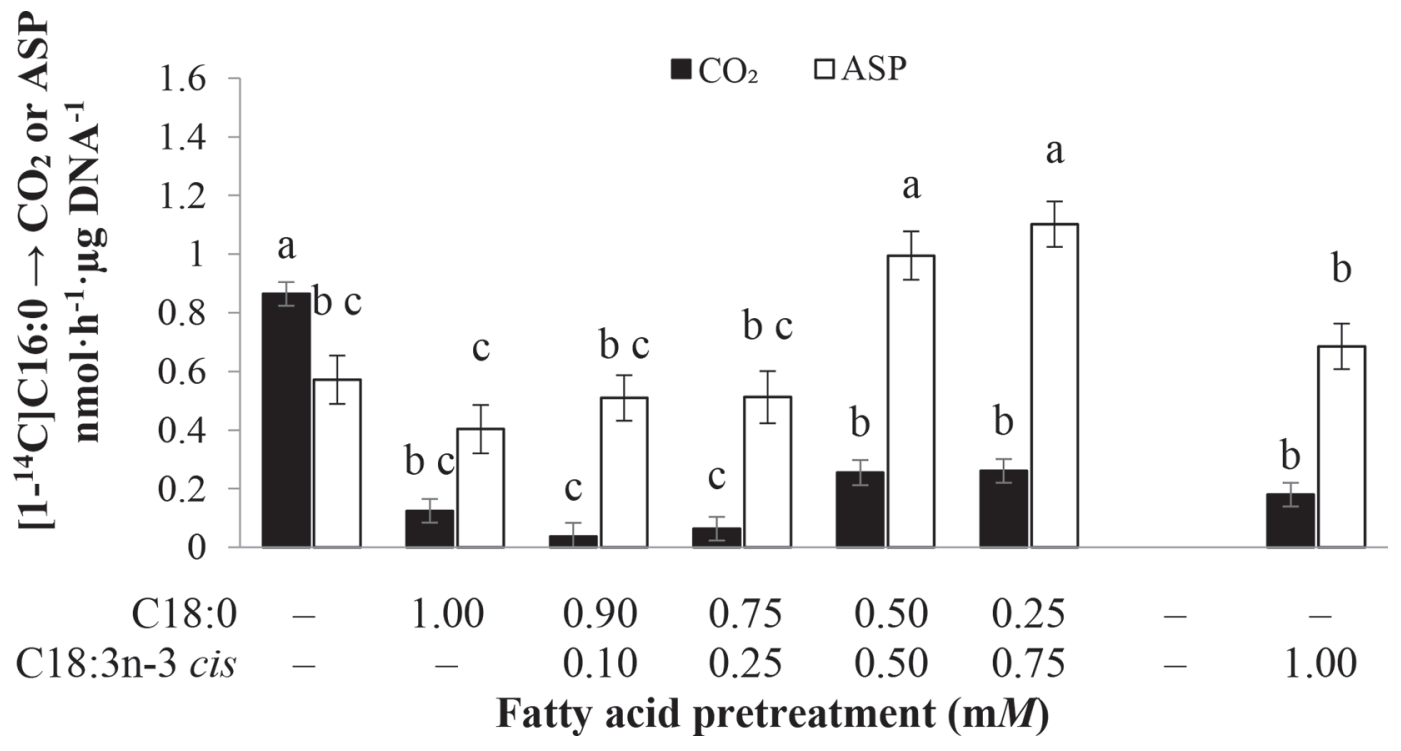

Figure 3. Oxidation of $\left[1-{ }^{14} \mathrm{C}\right] \mathrm{C} 16: 0$ to $\mathrm{CO}_{2}$ or acid-soluble products (ASP) after pretreatment with C18:0 and C18:3n-3 cis. Oxidation by Madin-Darby bovine kidney (MDBK) cells was measured over a 3-h period after 21-h pretreatments with BSA-bound fatty acids (FA). Fatty acid pretreatments were either single fatty acids (C18:0 or C18:3n-3 cis) or combinations of C18:0 with C18:3n-3 cis in the molar ratios listed. All treatments totaled $1.0 \mathrm{~m} M$ in Dulbecco's modified Eagle's medium (DMEM) with 1\% BSA. Control is DMEM with 1\% BSA and no additional FA. Data are reported as least squares means for 3 separate cell preparations with associated standard errors. Within substrate fraction, $\mathrm{CO}_{2}$ or ASP, means without a common letter $(\mathrm{a}-\mathrm{c})$ differ $(P<0.05)$.

NEFA levels in transition dairy cows (Rukkwamsuk et al., 1999). In contrast with a normal physiological setting, treatments of single fatty acids alone were included in the current study to evaluate the effect of individual fatty acids on subsequent partitioning and metabolism. Plasma NEFA profiles during the periparturient period are primarily comprised of $\mathrm{C} 16: 0, \mathrm{C} 18: 0$, and $\mathrm{C} 18: 1$ fatty acids, and C18:0 levels have been shown to peak at calving whereas C18:1 levels are similar pre- and postpartum (Rukkwamsuk et al., 1999; Douglas et al., 2007). These data merited selection of the fatty acids evaluated in the current study.

The ability to increase the cellular capacity for NEFA $\beta$-oxidation has been extensively discussed (Drackley and Andersen, 2006). Potential influences to NEFA oxidation have been examined through effects of pyruvate (Lomax et al., 1983; Armentano et al., 1991; Drackley et al., 1991), which raises the question of relationship to $\mathrm{PC}$ activity and links to the current research. Addition of pyruvate to hepatocytes isolated from fasted and fed sheep stimulated C16:0 complete oxidation to $\mathrm{CO}_{2}$ (Lomax et al., 1983). Pyruvate was shown to decrease triglyceride accumulation from C18:1n-9 cis in isolated hepatocytes from lactating goats (Armentano et al., 1991). A comprehensive study of biopsy samples from multiparous dairy cows also demonstrated the ability of pyruvate to increase C16:0 oxidation (Drackley et al., 1991). Any alterations to $P C$ mRNA expression or enzyme activity concurrent with changes in NEFA me- tabolism were not examined in previous studies, so the direct influence of NEFA on PC activity or flux toward anaplerosis or cataplerosis was not determined.

Previous research in rodents examined the effects of dietary sources of long-chain fatty acids and their influence on $\beta$-oxidation (Malewiak et al., 1988; Kumamoto and Ide, 1998). Metabolism of C18:1n-9 cis in isolated hepatocytes from fat-fed rats resulted in an increase in ASP formation and an increase in esterification to triglycerides compared with isolated hepatocytes from control animals (Malewiak et al., 1988). Although data from the current study demonstrated significantly $(P$ $<0.05)$ greater production of ASP from $\left[1-{ }^{14} \mathrm{C}\right] \mathrm{C} 16: 0$ compared with $\mathrm{CO}_{2}$ for all fatty acid pretreatments examined (Figures 2, 3, and 4), production of $\mathrm{CO}_{2}$ from $\left[1-{ }^{14} \mathrm{C}\right] \mathrm{C} 16: 0$ was greater after fatty acid pretreatment with $\mathrm{C} 18: 1 \mathrm{n}-9$ cis alone compared with pretreatment combinations containing C18:3n-3 cis (Figure 4). Interestingly, increased rates of both mitochondrial and peroxisomal C16:0 oxidation are seen in isolated hepatocytes from rats fed a fat mixture high in 18:3n-3 cis compared with C16:0 oxidation from rats fed sources of C16:0 or C18:2n-6 cis (Kumamoto and Ide, 1998), indicating the potential for differences in responses to fatty acids between ruminants and nonruminants or differences between in vitro experiments and those examining dietary fat sources.

Pearson coefficient correlations were used to associate $P C$ mRNA expression and rate of $\left[1-{ }^{14} \mathrm{C}\right] \mathrm{C} 16: 0$ me- 


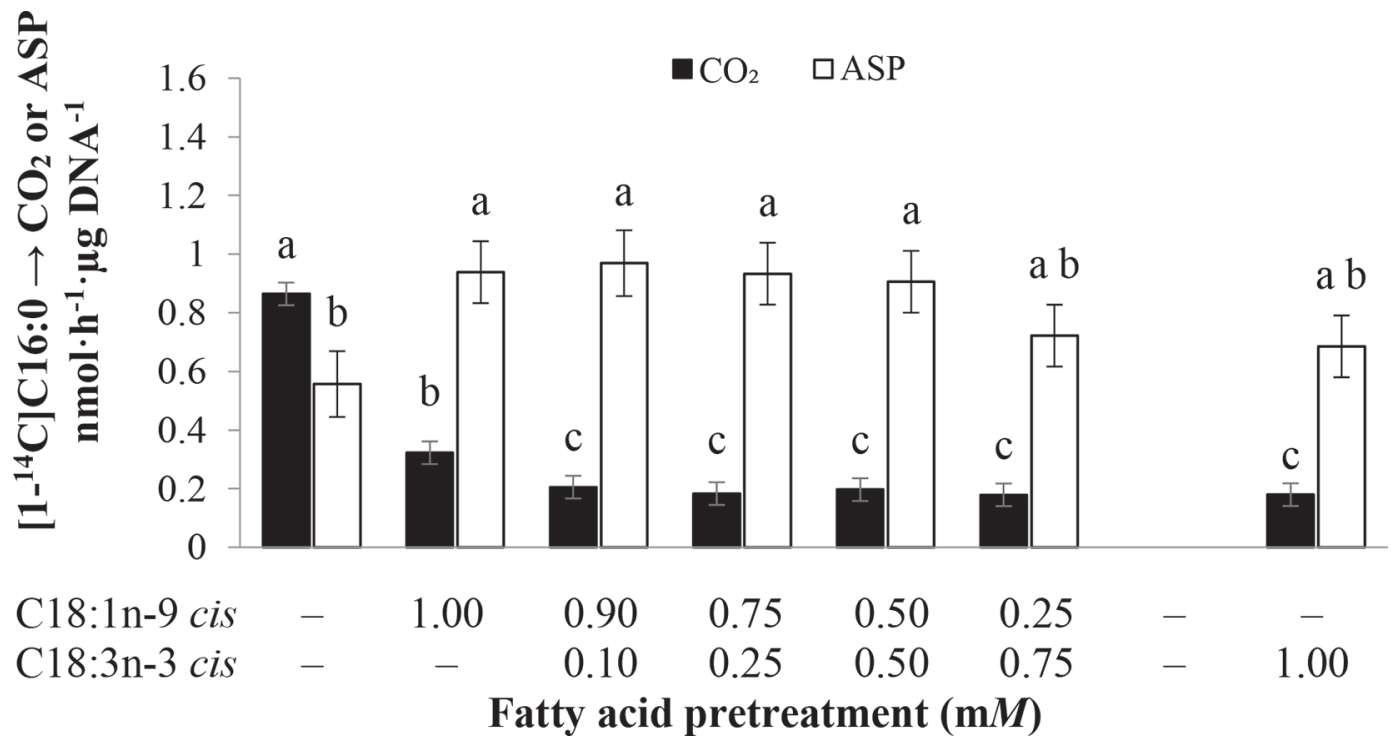

Figure 4. Oxidation of $\left[1-{ }^{14} \mathrm{C}\right] \mathrm{C} 16: 0$ to $\mathrm{CO}_{2}$ or acid-soluble products (ASP) after pretreatment with $\mathrm{C} 18: 1 \mathrm{n}-9$ cis and C18:3n-3 cis. Oxidation by Madin-Darby bovine kidney (MDBK) cells was measured over a 3-h period after 21-h pretreatments with BSA-bound fatty acids (FA). Fatty acid pretreatments were either single fatty acids (C18:1n-9 cis or C18:3n-3 cis) or combinations of C18:1n-9 cis with C18:3n-3 cis in the molar ratios listed. All treatments totaled $1.0 \mathrm{~m} M$ in Dulbecco's modified Eagle's medium (DMEM) with 1\% BSA. Control is DMEM with 1\% BSA and no additional FA. Data are reported as least squares means for 3 separate cell preparations with associated standard errors. Within substrate fraction, $\mathrm{CO}_{2}$ or ASP, means without a common letter $(\mathrm{a}-\mathrm{c})$ differ $(P<0.05)$.

tabolism to $\mathrm{CO}_{2}$ or ASP, including ketones. Production of $\mathrm{CO}_{2}$ from $\left[1-{ }^{14} \mathrm{C}\right] \mathrm{C} 16: 0$ was positively correlated $(\mathrm{r}=$ $0.63, P<0.05)$ with $P C$ expression, whereas ASP production from $\left[1-{ }^{14} \mathrm{C}\right] \mathrm{C} 16: 0$ only tended to be positively correlated $(\mathrm{r}=0.51,0.05<P<0.01)$ with $P C$ mRNA expression (Figure 5). Previous research using bovine primary hepatocytes examined the effects of 3-h exposure to C16:0 alone or concurrent exposure to C16:0 combined with several different UFA on subsequent mitochondrial and peroxisomal oxidation (Mashek et al., 2002). Results demonstrate increased oxidation of fatty acids to $\mathrm{CO}_{2}$ when treatment combinations of C16:0 with either C20:5n-3 cis (eicosapentaenoic acid; EPA) or C22:6n-3 cis (docosahexaenoic acid; DHA) were introduced to hepatocytes for $3 \mathrm{~h}$ compared with fatty acid treatments of C16:0 alone or C16:0 with C18:1 (Mashek et al., 2002). Similarly, 3-h treatment of bovine hepatocytes with $\mathrm{C} 16: 0$ with either C18:3, C20: 5n-3 cis, or C22:6n-3 cis reduced total cellular lipid deposition from C16:0 metabolism (Mashek et al., 2002). Results also indicated that PUFA, including C18:3n-3 cis, were poor substrates for esterification to triglycerides (Mashek et al., 2002). Although esterification of substrates to triglyceride formation was not measured in the current study, limitation of triglyceride formation by $\mathrm{C} 18: 3 \mathrm{n}-3$ cis in a primary hepatocyte model illustrates the potential for promotion through other fates - namely oxidation - of fatty acids after C18:3n-3 cis exposure in bovine. Although a very similar experiment was completed after 48-h treatments in hepatocyte monolayer cultures, the system did not concurrently measure complete oxidation to $\mathrm{CO}_{2}$, and only data for ASP production are available (Mashek and Grummer, 2003). Treatment of bovine hepatocytes with C18:0 included in the treatment medium resulted in the highest rates of ASP production from C16:0 (Mashek and Grummer, 2003). Taken together, these data indicate a potential role for SFA in the promotion of substrate metabolism to ASP, perhaps linked to UFA as a poor substrate for triglyceride esterification and promotion of substrate metabolism to $\mathrm{CO}_{2}$.

Studies examining the influence of $\mathrm{C} 18: 3 \mathrm{n}-3$ cis on hepatic fatty acid metabolism in rodents indicate that rats fed linseed oil had increased activity of enzymes involved in mitochondrial and peroxisomal $\beta$-oxidation when fed this source of C18:3n-3 cis (Kabir and Ide, 1996). Enzymes for fatty acid oxidation were also increased in rats fed C18:3n-3 cis enzyme activity from rats receiving dietary sources of either C18:2n-6 cis or C16:0 (Kumamoto and Ide, 1998). These data further support the role for C18:3n-3 cis in promoting fatty acid oxidation pathways.

Finally, Pearson coefficient correlations were also used to associate PCK1 mRNA expression and rate of $\left[1-{ }^{14} \mathrm{C}\right] \mathrm{C} 16: 0$ metabolism to $\mathrm{CO}_{2}$ or ASP. Production of $\mathrm{CO}_{2}$ or ASP from $\left[1-{ }^{14} \mathrm{C}\right] \mathrm{C} 16: 0$ were both positively cor- 

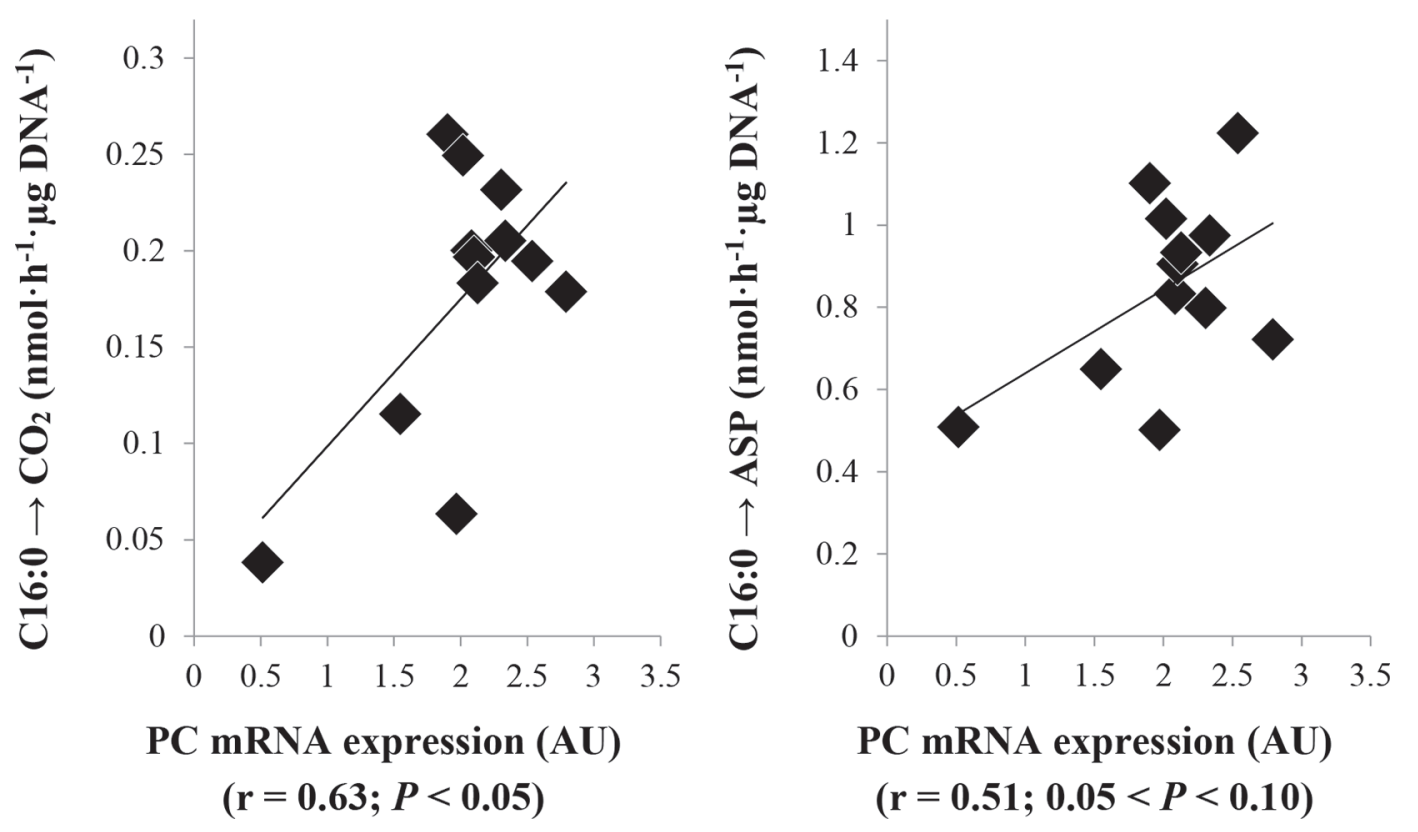

Figure 5. Relationship between pyruvate carboxylase $(P C)$ mRNA expression and rate of C16:0 metabolism to $\mathrm{CO}_{2}$ or acid-soluble products (ASP), including ketones. Madin-Darby bovine kidney (MDBK) cells at $80 \%$ confluence were cultured with BSA-bound fatty acids (FA) for 24 $\mathrm{h}$ (mRNA expression) or $21 \mathrm{~h}$ (substrate oxidation). Fatty acid treatments were combinations of fatty acids in 0.10:0.90, 0.25:0.75, 0.50:0.50, or 0.75:0.25 molar ratios from combinations of C16:0/C18:3n-3 cis, and in 0.25:0.75, 0.50:0.50, 0.75:0.25, or 0.90:0.10 molar ratios from combinations of C18:0/C18:3n-3 cis, or C18:1n-9 cis/C18:3n-3 cis. All treatments totaled $1.0 \mathrm{mM}$ in Dulbecco's modified Eagle's medium (DMEM) with $1 \%$ BSA. Data are reported as least squares means for 3 separate cell preparations. Pearson correlation coefficients for PC mRNA expression and nanomoles of ${ }^{14} \mathrm{C}$ substrate conversion to either ${ }^{14} \mathrm{CO}_{2}$ or ASP $\left(\right.$ per $\mu \mathrm{g} \mathrm{DNA}{ }^{-1} \cdot \mathrm{h}^{-1}$ ) are shown.

related $(\mathrm{r}=0.80$ and $\mathrm{r}=0.69$, respectively; $P<0.05)$ with $P C K 1$ expression (Figure 6). Understanding the balance of PC and PCK1 activities is key to determining the net anaplerotic or cataplerotic pull of TCA cycle carbons. To maximize the energy production potential of both systems, there is a need to identify agents or combinations of agents that independently activate PC to promote fatty acid $\beta$-oxidation and TCA cycle capacity. Such an agent would simultaneously maintain, but not increase, PCK1 activity to fulfill the need for carbon pull to gluconeogenesis.

The present data establish a relationship between regulation of $P C$ mRNA expression by fatty acids and cellular oxidative capacity. Although additional research is needed to establish the mechanisms by which fatty acids act to modulate $P C$ mRNA expression, evidence is accumulating for a role of PPAR- $\alpha$. Research on hepatocyte isolations from 7-wk-old calves after 5 -d administration of either fish oil or clofibrate, a PPAR- $\alpha$ agonist, found an increased rate of $\mathrm{C} 16: 0$ conversion to $\mathrm{CO}_{2}$ in 8-h incubations from clofibrate-treated calves, compared with fish oil- or control-treated hepatocyte isolations (Litherland et al., 2010), indicating an increase in capacity for fatty acid $\beta$-oxidation. An even greater increase in substrate oxidation to $\mathrm{CO}_{2}$ is seen in lactating goats treated with $\mathrm{Wy}-14643$, a known
PPAR- $\alpha$ agonist (Cappon et al., 2002). Furthermore, previous research from our laboratory indicates a response of bovine PC proximal promoter to PPAR- $\alpha$ agonist (White et al., 2011). Increased mRNA expression of acyl-CoA dehydrogenase and PPAR- $\alpha$ both occur during early lactation (Loor et al., 2005) and may link increases in PC at calving to elevated fatty acid $\beta$-oxidation in transition cows. In further support of this aspect, increases in mRNA expression for genes involved in fatty acid $\beta$-oxidation, including acyl-CoA synthetase long chain, carnitine palmitoyl-transferase $1 \mathrm{~A}$, and acyl-CoA dehydrogenase very long chain, are seen after parturition in liver samples from transition dairy cows (Loor, 2010; Weber et al., 2013).

The transition to lactation, transient feed restriction, the interval around the weaning transition in calves, and the response to elevated glucocorticoids with stress, or exogenously administrated glucocorticoids all represent physiological conditions in dairy cattle that are accompanied by elevated plasma NEFA. Our goal was to determine effects of the elevated co-presence of SFA and UFA pretreatments on cellular partitioning of fatty acid metabolism in a bovine model of cellular energy metabolism. The proportions of fatty acids tested were intended to represent the extremes of SFA to UFA ratios. Although these single and dual mixtures 


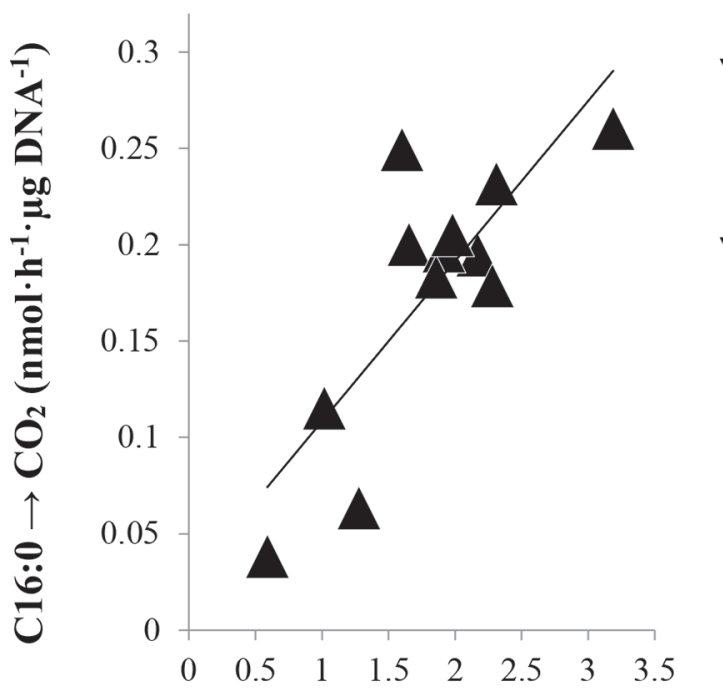

PCK1 mRNA expression (AU)

$$
(\mathrm{r}=0.80 ; P<0.05)
$$

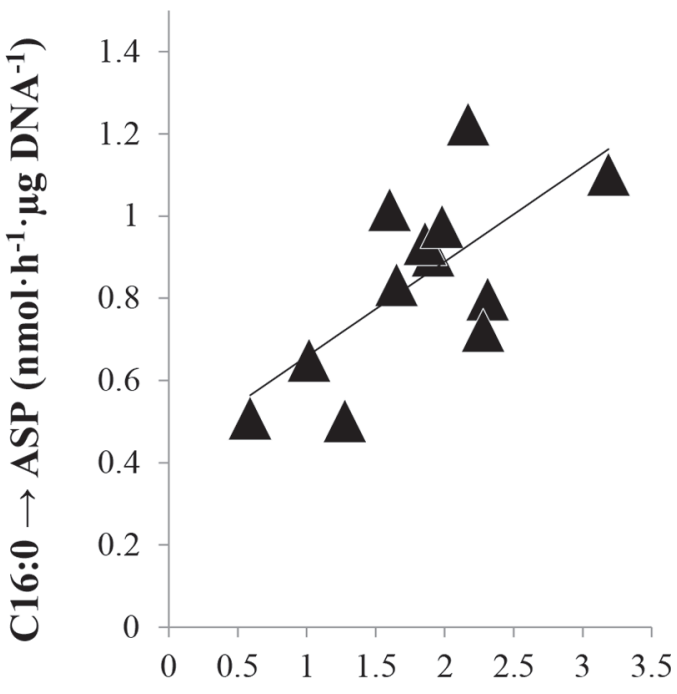

PCK1 mRNA expression (AU)

$$
(\mathrm{r}=0.69 ; P<0.05)
$$

Figure 6. Relationship between cytosolic phosphoenolpyruvate carboxykinase ( $P C K 1)$ mRNA expression and rate of C16:0 metabolism to $\mathrm{CO}_{2}$ or acid-soluble products (ASP), including ketones. Madin-Darby bovine kidney (MDBK) cells at $80 \%$ confluence were cultured with BSA-bound fatty acids (FA) for $24 \mathrm{~h}$ (mRNA expression) or $21 \mathrm{~h}$ (substrate oxidation). Fatty acid treatments were combinations of fatty acids in 0.10:0.90, 0.25:0.75, 0.50:0.50, or 0.75:0.25 molar ratios from combinations of C16:0/C18:3n-3 cis, and in 0.25:0.75, 0.50:0.50, 0.75:0.25, or 0.90:0.10 molar ratios from combinations of C18:0/C18:3n-3 cis, or C18:1n-9 cis/C18:3n-3 cis. All treatments totaled 1.0 mM in Dulbecco's modified Eagle's medium (DMEM) with 1\% BSA. Data are reported as least squares means for 3 separate cell preparations. Pearson correlation coefficients for PCK1 mRNA expression and nanomoles of ${ }^{14} \mathrm{C}$ substrate conversion to either ${ }^{14} \mathrm{CO}_{2}$ or $\mathrm{ASP}\left(\right.$ per $\left.\mu \mathrm{g} \mathrm{DNA}^{-1} \cdot \mathrm{h}^{-1}\right)$ are shown.

of fatty acids represent extremes and are not likely to occur in vivo, there are examples where C18:3n-3 is elevated. Concentrations of $\mathrm{C} 18: 3 \mathrm{n}-3$ represented $10 \%$ of total fatty acids in lactating cows fed extruded flaxseed (Gonthier et al., 2004), 7\% C18:3n-3 has been observed in plasma from cows fed flaxseed oil from prepartum through 100 DIM (Moallem et al., 2013), and plasma concentration of $17 \%$ C18:3n-3 has been observed in preweaned calves fed flaxseed oil in milk replacer (Schossow, 2019). In this study, we indicated the potential of $\mathrm{C} 18: 3 \mathrm{n}-3$ cis to affect $\mathrm{PC}$ expression and fatty acid concentration. Further effort is needed to determine the potential role of elevated C18:3n-3 on modulating the capacity for fatty acid oxidation in vivo in both cows and calves. Likewise, information on the responses to elevated C18:3n-3 when present in complex mixtures of fatty acids is needed to provide a more complete understanding of the role of $\mathrm{C} 18: 3 \mathrm{n}$ -3 in regulating PC and PCK1 expression and lipid metabolism in dairy cattle. A working hypothesis for the role of $\mathrm{PC}$ in determining cellular partitioning of fatty acid metabolism to either complete or partial oxidation is supported by the correlation of $P C$ mRNA expression to substrate oxidation to $\mathrm{CO}_{2}$. Additional experiments are needed to determine whether a similar relationship holds for bovine liver as for the MDBK cell model examined here.

\section{CONCLUSIONS}

We demonstrated regulation of ketone production by MDBK cells in response to saturated and unsaturated fatty acid pretreatments. Although oxidation of $\left[1-{ }^{14} \mathrm{C}\right]$ C16:0 to either $\mathrm{CO}_{2}$ or ASP was depressed by treatments with the SFA C16:0 or C18:0 alone, correlation of $\mathrm{CO}_{2}$ values to $P C$ mRNA expression indicated the potential for increased anaplerotic flux of substrates through PC. We detected a tendency for correlation of ASP oxidation values with $P C$ mRNA expression, implying either inadvertent activation of enzymes involved in ketogenesis or activation of other enzymes, including PCK1, involved in gluconeogenesis.

\section{ACKNOWLEDGMENTS}

This work was supported by grant no. 2009-3590005970 from the USDA National Institute of Food and Agriculture (Washington, DC). The authors have not stated any conflicts of interest.

\section{REFERENCES}

Armentano, L. E., R. R. Grummer, S. J. Bertics, T. C. Skaar, and S. S. Donkin. 1991. Effects of energy balance on hepatic capacity for oleate and propionate metabolism and triglyceride secre- 
tion. J. Dairy Sci. 74:132-139. https://doi.org/10.3168/jds.S0022 -0302(91)78153-8.

Berry, M. N., A. M. Edwards, and G. J. Barritt. 1991. Biochemical properties. Pages 121-178 in Laboratory Techniques in Biochemistry and Molecular Biology. Isolated Hepatocytes Preparation, Properties and Applications. Vol. 21. R. H. Burdon and P. H. van Knippenberg, ed. Elsevier, Amsterdam, the Netherlands.

Bionaz, M., C. R. Baumrucker, E. Shirk, J. P. Vanden Heuvel, E. Block, and G. A. Varga. 2008a. Characterization of Madin-Darby bovine kidney cell line for peroxisome proliferator-activated receptors: Temporal response and sensitivity to fatty acids. J. Dairy Sci. 91:2808-2813. https://doi.org/10.3168/jds.2007-0789.

Bionaz, M., R. E. Everts, H. A. Lewin, J. K. Drackley, and J. J. Loor. 2008b. Bovine kidney (MDBK) cells and liver tissue of periparturient cows share remarkable similarity in gene expression profiles. J. Dairy Sci. 91(Suppl. 1):178. (Abstr.)

Bizeau, M. E., C. Short, J. S. Thresher, S. R. Commerford, W. T. Willis, and M. J. Pagliassotti. 2001. Increased pyruvate flux capacities account for diet-induced increases in gluconeogenesis in vitro. Am. J. Physiol. Regul. Integr. Comp. Physiol. 281:R427-R433. https:/ /doi.org/10.1152/ajpregu.2001.281.2.R427.

Bobe, G., J. W. Young, and D. C. Beitz. 2004. Invited review: Pathology, etiology, prevention, and treatment of fatty liver in dairy cows. J. Dairy Sci. 87:3105-3124. https://doi.org/10.3168/jds .S0022-0302(04)73446-3.

Cappon, G. D., R. C. M. Liu, S. R. Frame, and M. E. Hurtt. 2002. Effects of the rat hepatic peroxisome proliferator, Wyeth-14,643, on the lactating goat. Drug Chem. Toxicol. 25:255-266. https:// doi.org/10.1081/DCT-120005888.

Chen, L., C. Wang, S. Huang, B. Gong, J. Yu, Q. Shi, and G. Chen. 2014. Effects of individual and multiple fatty acids (palmitate, oleate and docosahexaenoic acid) on cell viability and lipid metabolism in LO2 human liver cells. Mol. Med. Rep. 10:3254-3260. https://doi.org/10.3892/mmr.2014.2579.

Contreras, G. A., N. J. O'Boyle, T. H. Herdt, and L. M. Sordillo. 2010. Lipomobilization in periparturient dairy cows influences the composition of plasma nonesterified fatty acids and leukocyte phospholipid fatty acids. J. Dairy Sci. 93:2508-2516. https://doi.org/ 10.3168/jds.2009-2876.

Donkin, S. S., and L. E. Armentano. 1994. Regulation of gluconeogenesis by insulin and glucagon in the neonatal bovine. Am. J. Physiol. 266:R1229-R1237. https://doi.org/10.1152/ajpregu.1994 266.4.R1229.

Douglas, G. N., J. Rehage, A. D. Beaulieu, A. O. Bahaa, and J. K. Drackley. 2007. Prepartum nutrition alters fatty acid composition in plasma, adipose tissue, and liver lipids of periparturient dairy cows. J. Dairy Sci. 90:2941-2959. https://doi.org/10.3168/jds.2006 -225 .

Drackley, J. K., and J. B. Andersen. 2006. Splanchnic metabolism of long-chain fatty acids in ruminants. Pages 199-224 in Ruminant Physiology: Digestion, Metabolism and Impact of Nutrition on Gene Expression, Immunology and Stress. Proc. 10th Int. Symp. Ruminant Physiology, Copenhagen, Denmark. K. Sejrsen, T. Hvelplund, and M. O. Nielsen, ed. Wageningen Academic Publishers, Utrecht, the Netherlands.

Drackley, J. K., A. D. Beaulieu, and J. P. Elliott. 2001. Responses of milk fat composition to dietary fat or nonstructural carbohydrates in Holstein and Jersey cows. J. Dairy Sci. 84:1231-1237. https:// doi.org/10.3168/jds.S0022-0302(01)74584-5.

Drackley, J. K., D. C. Beitz, and J. W. Young. 1991. Regulation of in vitro palmitate oxidation in liver from dairy cows during early lactation. J. Dairy Sci. 74:1884-1892. https://doi.org/10.3168/jds .S0022-0302(91)78354-9.

Emery, R. S., J. Liesman, and T. Herdt. 1992. Metabolism of long chain fatty acids by ruminant liver. J. Nutr. 122(Suppl_3):832-837. https://doi.org/10.1093/jn/122.suppl_3.832.

Gonthier, C., A. F. Mustafa, R. Berthiaume, H. V. Petit, R. Martineau, and D. R. Ouellet. 2004. Effects of feeding micronized and extruded flaxseed on ruminal fermentation and nutrient utilization by dairy cows. J. Dairy Sci. 87:1854-1863. https://doi.org/10 .3168/jds.S0022-0302(04)73343-3.
Greenfield, R. B., M. J. Cecava, and S. S. Donkin. 2000. Changes in mRNA expression for gluconeogenic enzymes in liver of dairy cattle during the transition to lactation. J. Dairy Sci. 83:1228-1236. https://doi.org/10.3168/jds.S0022-0302(00)74989-7.

Grum, D. E., J. K. Drackley, R. S. Younker, D. W. LaCount, and J. J. Veenhuizen. 1996. Nutrition during the dry period and hepatic lipid metabolism of periparturient dairy cows. J. Dairy Sci. 79:18501864. https://doi.org/10.3168/jds.S0022-0302(96)76553-0.

Hagopian, K., J. J. Ramsey, and R. Weindruch. 2004. Krebs cycle enzymes from livers of old mice are differentially regulated by caloric restriction. Exp. Gerontol. 39:1145-1154. https://doi.org/10.1016/ j.exger.2004.04.009.

Huang, C., Y. Kim, M. L. Caramori, J. H. Moore, S. S. Rich, J. C. Mychaleckyj, P. C. Walker, and M. Mauer. 2006. Diabetic nephropathy is associated with gene expression levels of oxidative phosphorylation and related pathways. Diabetes 55:1826-1831. https://doi.org/10.2337/db05-1438.

Ide, T., H. Kobayashi, L. Ashakumary, I. A. Rouyer, Y. Takahashi, T. Aoyama, T. Hashimoto, and M. Mizugaki. 2000. Comparative effects of perilla and fish oils on the activity and gene expression of fatty acid oxidation of enzymes in rat liver. Biochim. Biophys. Acta 1485:23-35. https://doi.org/10.1016/S1388-1981(00)00026-3

Ikeda, I., J. Y. Cha, T. Yanagita, N. Nakatani, K. Oogami, K. Imaizumi, and K. Yazawa. 1998. Effects of dietary $\alpha$-linolenic, eicosapentaenoic, and docosahexaenoic acids on hepatic lipogenesis and $\beta$-oxidation in rats. Biosci. Biotechnol. Biochem. 62:675-680. https://doi.org/10.1271/bbb.62.675.

Jesse, B. W., R. S. Emery, and J. W. Thomas. 1986. Aspects of the regulation of long-chain fatty acid oxidation in bovine liver. J. Dairy Sci. 69:2298-2303. https://doi.org/10.3168/jds.S0022 -0302(86)80668-3.

Jitrapakdee, S., A. Vidal-Puig, and J. C. Wallace. 2006. Anaplerotic roles of pyruvate carboxylase in mammalian tissues. Cell. Mol. Life Sci. 63:843-854. https://doi.org/10.1007/s00018-005-5410-y.

Jump, D. B. 2008. N-3 polyunsaturated fatty acid regulation of hepatic gene transcription. Curr. Opin. Lipidol. 19:242-247. https:// doi.org/10.1097/MOL.0b013e3282ffaf6a.

Kabir, Y., and T. Ide. 1996. Activity of hepatic fatty acid oxidation enzymes in rats fed alpha-linolenic acid. Biochim. Biophys. Acta 1304:105-119. https://doi.org/10.1016/S0005-2760(96)00110-5.

Kleppe, B. B., R. J. Aiello, R. R. Grummer, and L. E. Armentano. 1988. Triglyceride accumulation and very low density lipoprotein secretion by rat and goat hepatocytes in vitro. J. Dairy Sci. 71:1813-1822. https://doi.org/10.3168/jds.S0022-0302(88)79750 $-7$.

Kumamoto, T., and T. Ide. 1998. Comparative effects of alpha- and gamma-linolenic acids on rat liver fatty acid oxidation. Lipids 33:647-654. https://doi.org/10.1007/s11745-998-0252-4.

Labarca, C., and K. Paigen. 1980. A simple, rapid, and sensitive DNA assay procedure. Anal. Biochem. 102:344-352. https://doi.org/10 .1016/0003-2697(80)90165-7.

Litherland, N. B., M. Bionaz, R. L. Wallace, J. J. Loor, and J. K. Drackley. 2010. Effects of the peroxisome proliferator-activated receptor-alpha agonists clofibrate and fish oil on hepatic fatty acid metabolism in weaned dairy calves. J. Dairy Sci. 93:2404-2418. https://doi.org/10.3168/jds.2009-2716.

Litherland, N. B., H. M. Dann, and J. K. Drackley. 2011. Prepartum nutrient intake alters palmitate metabolism by liver slices from peripartal dairy cows. J. Dairy Sci. 94:1928-1940. https://doi.org/ $10.3168 /$ jds.2010-3220

Lomax, M. A., I. A. Donaldson, and C. I. Pogson. 1983. The control of fatty acid metabolism in liver cells from fed and starved sheep. Biochem. J. 214:553-560. https://doi.org/10.1042/bj2140553.

Loor, J. J. 2010. Genomics of metabolic adaptations in the peripartal cow. Animal 4:1110-1139. https://doi.org/10.1017/ S1751731110000960.

Loor, J. J., H. M. Dann, R. E. Everts, R. Oliveira, C. A. Green, N. A. Guretzky, S. L. Rodriguez-Zas, H. A. Lewin, and J. K. Drackley. 2005. Temporal gene expression profiling of liver from periparturient dairy cows reveals complex adaptive mechanisms in hepatic 
function. Physiol. Genomics 23:217-226. https://doi.org/10.1152/ physiolgenomics.00132.2005.

Malewiak, M. I., R. Rozen, X. Le Liepvre, and S. Griglio. 1988. Oleate metabolism and endogenous triacylglycerol hydrolysis in isolated hepatocytes from rats fed a high-fat diet. Diabete Metab. 14:270-276.

Mashek, D. G., S. J. Bertics, and R. R. Grummer. 2002. Metabolic fates of long-chain unsaturated fatty acids and their effects on palmitic acid metabolism and gluconeogenesis in bovine hepatocytes. J. Dairy Sci. 85:2283-2289. https://doi.org/10.3168/jds.S0022 -0302(02)74308-7.

Mashek, D. G., and R. R. Grummer. 2003. Effects of long chain fatty acids on lipid and glucose metabolism in monolayer cultures of bovine hepatocytes. J. Dairy Sci. 86:2390-2396. https://doi.org/ 10.3168/jds.S0022-0302(03)73833-8.

Moallem, U., A. Shafran, M. Zachut, I. Dekel, Y. Portnick, and A. Arieli. 2013. Dietary $\alpha$-linolenic acid from flaxseed oil improved folliculogenesis and IVF performance in dairy cows, similar to eicosapentaenoic and docosahexaenoic acids from fish oil. Reproduction 146:603-614. https://doi.org/10.1530/REP-13-0244.

Murondoti, A., R. Jorritsma, A. C. Beynen, T. Wensing, and M. J. H. Geelen. 2004. Unrestricted feed intake during the dry period impairs the postpartum oxidation and synthesis of fatty acids in the liver of dairy cows. J. Dairy Sci. 87:672-679. https://doi.org/ 10.3168/jds.S0022-0302(04)73210-5.

Ricchi, M., M. R. Odoardi, L. Carulli, C. Anzivino, S. Ballestri, A. Pinetti, L. I. Fantoni, F. Marra, M. Bertolotti, S. Banni, A. Lonardo, N. Carulli, and P. Loria. 2009. Differential effect of oleic and palmitic acid on lipid accumulation and apoptosis in cultured hepatocytes. J. Gastroenterol. Hepatol. 24:830-840. https://doi .org/10.1111/j.1440-1746.2008.05733.x.

Rukkwamsuk, T., M. J. Geelen, T. A. Kruip, and T. Wensing. 2000. Interrelation of fatty acid composition in adipose tissue, serum, and liver of dairy cows during the development of fatty liver postpartum. J. Dairy Sci. 83:52-59. https://doi.org/10.3168/jds.S0022 -0302(00)74854-5.

Rukkwamsuk, T., T. A. Kruip, G. A. Meijer, and T. Wensing. 1999. Hepatic fatty acid composition in periparturient dairy cows with fatty liver induced by intake of a high energy diet in the dry period. J. Dairy Sci. 82:280-287. https://doi.org/10.3168/jds.S0022 -0302(99)75234-3.

Salto, R., M. Sola, F. J. Oliver, and A. M. Vargas. 1996. Effects of starvation, diabetes and carbon tetrachloride intoxication on rat kidney cortex and liver pyruvate carboxylase levels. Arch. Physiol. Biochem. 104:845-850. https://doi.org/10.1076/apab.104.7.845 .13111

Sartorelli, P., S. Dominoni, and F. Agnes. 1992. Influence of duration of simulated transport on plasma stress markers in the calf. J. Vet. Med. 39:401-403.

Schossow, C. R. 2019. Evaluation of flax oil supplementation on performance of growing dairy heifer calves and lactating cows. MS
Thesis. Dairy Science Department, South Dakota State University, Brookings. https://openprairie.sdstate.edu/etd/3140.

Thering, B. J., M. Bionaz, and J. J. Loor. 2009. Long-chain fatty acid effects on peroxisome proliferator-activated receptor- $\alpha$-regulated genes in Madin-Darby bovine kidney cells: Optimization of culture conditions using palmitate. J. Dairy Sci. 92:2027-2037. https://doi .org/10.3168/jds.2008-1749.

van Knegsel, A. T., H. van den Brand, J. Dijkstra, S. Tamminga, and B. Kemp. 2005. Effect of dietary energy source on energy balance, production, metabolic disorders and reproduction in lactating dairy cattle. Reprod. Nutr. Dev. 45:665-688. https://doi.org/ 10.1051/rnd:2005059.

Velez, J. C., and S. S. Donkin. 2005. Feed restriction induces pyruvate carboxylase but not phosphoenolpyruvate carboxykinase in dairy cows. J. Dairy Sci. 88:2938-2948. https://doi.org/10.3168/ jds.S0022-0302(05)72974-X.

Weber, C., C. Hametner, A. Tuchscherer, B. Losand, E. Kanitz, W. Otten, H. Sauerwein, R. M. Bruckmaier, F. Becker, W. Kanitz, and H. M. Hammon. 2013. Hepatic gene expression involved in glucose and lipid metabolism in transition cows: Effects of fat mobilization during early lactation in relation to milk performance and metabolic changes. J. Dairy Sci. 96:5670-5681. https://doi .org/10.3168/jds.2012-6277.

White, H. M., S. L. Koser, and S. S. Donkin. 2011. Differential regulation of bovine pyruvate carboxylase promoters by fatty acids and peroxisome proliferator-activated receptor- $\alpha$ agonist. J. Dairy Sci. 94:3428-3436. https://doi.org/10.3168/jds.2010-3960.

White, H. M., S. L. Koser, and S. S. Donkin. 2012. Gluconeogenic enzymes are differentially regulated by fatty acid cocktails in MadinDarby bovine kidney cells. J. Dairy Sci. 95:1249-1256. https://doi .org/10.3168/jds.2011-4644.

Zhang, Y., L. Dong, X. Yang, H. Shi, and L. Zhang. 2011. $\alpha$-Linolenic acid prevents endoplasmic reticulum stress-mediated apoptosis of stearic acid lipotoxicity on primary rat hepatocytes. Lipids Health Dis. 10:81. https://doi.org/10.1186/1476-511X-10-81.

Zhang, Q., S. L. Koser, B. J. Bequette, and S. S. Donkin. 2015. Effect of propionate on mRNA expression of key genes for gluconeogenesis in liver of dairy cattle. J. Dairy Sci. 98:8698-8709. https://doi .org/10.3168/jds.2015-9590.

Zhang, Q., S. L. Koser, and S. S. Donkin. 2016. Propionate induces mRNA expression of gluconeogenic genes in bovine calf hepatocytes. J. Dairy Sci. 99:3908-3915. https://doi.org/10.3168/jds .2015-10312.

\section{ORCIDS}

K. E. Boesche ๑ https://orcid.org/0000-0001-9736-5361 S. S. Donkin (® https://orcid.org/0000-0003-3571-4946 